\title{
Assessment of Policing and Prevention Strategies of Stock Theft in South Africa: A Case Study of Giyani Policing Area, Republic of South Africa
}

\author{
Maluleke, W \\ Obioha, EE \\ Mofokeng, JT
}

Department of Safety and Security Management, Tshwane University of Technology, Pretoria, South Africa

Email: madlaya92@gmail.com, obiohaee@tut.ac.za \& mofokengjt@tut.ac.za

Doi:10.5901/mjss.2014.v5n23p2148

\begin{abstract}
This study assesses the effectiveness of current strategies employed on stock theft prevention and relationship maintenance within rural communities of Giyani Policing Area (GPA) of Limpopo province by using stock theft prevention as a framework. Specifically, the objective to the study was to assess the effectiveness of current strategies employed by the Giyani South African Police Service Stock Theft Unit (Giyani SAPS STU) in response to stock theft in Giyani communities. The study population consisted of 64 participants from various relevant stakeholders involved in preventing and combating of stock theft in the GPA. The main findings of the study show that a cloud of no confidence exists toward the police amongst the affected livestock farmers and community members, as stock theft is increasing, in the absence of an adequate deterrent (combating) strategy, or a preventative approach.
\end{abstract}

Keywords: Crime prevention, Giyani, Livestock, Policing, Stock theft, South Africa

\section{Introduction}

Overall, the purpose of this study was to gather data on, and determine, perceptions on stock theft prevention in the GPA, Limpopo Province; thus, identifying the challenges that face the Giyani SAPS STU, given its inadequate approach in dealing with stock theft in the surrounding areas. Livestock remains an absolute credit to Giyani families, villages across the policing areas, and the municipality, at large. However, the capacity of the Giyani SAPS STU and livestock farmers in respond to stock theft remains dent livestock protection to date. Literature highlights the fact that, not only do farmers suffer astronomical financial losses, they are also confronted with the cruelty, and mercilessness, of stock thieves in the handling, maiming, and slaughtering of the stolen animals. In sum, it is not only the farming community that suffers; stock theft has an impact on the total economy of the country (Geldenhuys, 2009, p. 49). This argument is supported by Butler (2011), who reported that the levels of stock theft, predation, and animal health in South Africa are the three main issues hampering agriculture from its potential to grow jobs, and alleviate poverty, according to the National Wool Growers' Association (NWGA). In this association's view, these three issues cost the country millions of rand annually, with stock theft alone stripping R450 million per year from the economy. Given this background, this study highlights stock theft prevention measures. In the light of this statement, the latest statistics (see Table 1 below), at the time of conducting the study, indicate that, seventy-one (71) cases of stock theft were reported in Giyani for the last financial year (April 2011 March 2012), which witnessed an increase as the second largest number of cases reported since April 2006 - March 2007, when seventy-nine (79) stock were reported stolen. Against this backdrop, and reviewing the latest statistics on stock theft in the GPA, it is evident that stock theft is increasing in the GPA, Limpopo Province; thus, highlighting the extent of the problem.

Table 1: Property-related crimes: Stock theft statistics (April 2003 - March 2012) (SAPS, 2012)

\begin{tabular}{|c|c|c|c|c|c|c|c|c|c|c|}
\hline $\begin{array}{c}\text { Crime } \\
\text { category }\end{array}$ & $\begin{array}{c}\text { April 2003 } \\
\text { to } \\
\text { March 2004 }\end{array}$ & $\begin{array}{c}\text { April 2004 } \\
\text { to } \\
\text { March 2005 }\end{array}$ & $\begin{array}{c}\text { April 2005 } \\
\text { to } \\
\text { March 2006 }\end{array}$ & $\begin{array}{c}\text { April 2006 } \\
\text { to } \\
\text { March 2007 }\end{array}$ & $\begin{array}{c}\text { April.2007 } \\
\text { to } \\
\text { March.2008 }\end{array}$ & $\begin{array}{c}\text { April 2008 } \\
\text { to } \\
\text { March 2009 }\end{array}$ & $\begin{array}{c}\text { April 2009 } \\
\text { to } \\
\text { March 2010 }\end{array}$ & $\begin{array}{c}\text { April 2010 } \\
\text { to } \\
\text { March 2011 }\end{array}$ & $\begin{array}{c}\text { April 2011 } \\
\text { to } \\
\text { March 2012 }\end{array}$ \\
\hline Stock-theft & 62 & 40 & 17 & 79 & 41 & 58 & 51 & 58 & 71 \\
\hline
\end{tabular}


In relative to the stock theft statistics presented above in the GPA, Crime Stats South Africa revealed that the worst ten stock theft precincts in 2012 were the following: (1) Lebowakgomo - 104; (2) Mankweng - 84; (3) Dennilton - 73; (4) Giyani - 71; (5) Matlala - 62; (6) Magatle - 61; (7) Letsitele -53; (8) Marble Hall - 53; (9) Nebo - 49; and, (10) Hlogotlou - 49, making a total of 659 reported stock theft crimes in the identified precincts. It is, therefore, apparent that Giyani residents are experiencing a high volume of stock theft; yet, neither the Giyani SAPS STU, nor livestock farmers, appear to have adequate capacity to respond to the challenges posed by these stock theft crimes. With that mentioned, for the purpose of this study is therefore to assess the effectiveness of current strategies employed by the Giyani SAPS STU in response to stock theft in Giyani communities.

\section{Research Methodology}

The study was conducted in the GPA of Limpopo Province. The specific locations for the target groups; namely: Giyani inner city, Makosha and Xikukwana villages were carefully selected, taking into consideration the demography and inhabitants of each area. (A detailed description of the study area is outlined below.). For the purpose of this study, a qualitative research approach was adopted to collect data, so as to examine, and assess, the actual perceptions and experiences of Giyani SAPS STU and, livestock owners in stock theft prevention. This was done through Focus Group Discussions (FGDs), in depth interviews with Key Informants (KIIs), and stock theft courtroom observation schedules.

The population of the sample of the study was made up of on the selected target groups, taken from GPA, and, Makosha and Xikukwana villages (Ward 14). The target groups were as follows: FGDs 1: SAPS officers attached to the local police station ( 8 - extracted from the inner city area); FGDs 2: Community members (12; 6 from each village - rural areas outside the city); Community Policing Forums (CPFs) managers (4; 2 from each village - rural areas outside the city); and, leaders of the local Faith-based organisations (4: 2 from each village). And FGDs 3: prominent local farmers (20; 10 from each village - rural areas outside the city). Klls were conducted in the inner city area with participants from the Giyani SAPS STU officers (7); Department of Agriculture (Veterinary Services; Land and Infrastructure; and, Natural Resource Management managers) (2); Mopani District officials (2; Community Researcher and a Community Liaison Officer); Giyani Municipality officials (2; Occupational Health and Safety Officer; Community Safety and Liaison Officer); and, Giyani Magistrates' Court personnel (3; Senior Prosecutor, Control Public Prosecutor; Court Interpreter). Overall 64 participants were selected based on: their knowledge of stock theft prevalence and the methods employed to curb it in the GPA, Limpopo Province.

\section{National and Regional Prevalence of Livestock Theft in South Africa}

The feature on stock theft ("The Witness", June 7) suggests that it is large scale white farmers who are mainly affected by this crime. Far from it, emerging, or small-scale Black farmers have suffered enormously from this scourge for decades. Unfortunately, most do not have access to radio networks, or rapid response facilities; so, the retrieval of their livestock is considerably jeopardised. Proportionately, their losses are more devastating than those of commercial farmers.Some years ago, a community of these farmers, who lived adjacent to the Sani Pass (Researcher's note: located at the Western end of KZN province of South Africa on the road between Underberg and Mokhotlong, Lesotho. It is a route that connects KZN and Lesotho) were frustrated by the apparently inadequate official measures, and after capture, applied "bush" punishment to the thieves, amputating their ears, and hands. Of course, the law descended on the farmers, who meted out the punishment, while the thieves got to spend a comfortable time being treated, fed, and sheltered in jail, before being released on a lack of evidence. Nevertheless, stock theft in that area declined post-haste (Collins, 2011: 11).

South Africa has been experiencing stock theft for years now; this argument is supported by the news report ("Independent Online") of 22/11/2007, which stated that stock theft in South Africa amounted to R327.6 million in 2006, according to the National Stock Theft Forum (NSTF). "At the moment, stock theft is hampering the profitability of the stock farmers, and it is also interfering with the government's land reform process, as well as the empowering of the emerging farmers", the Forum added. "For each stock theft incident at a commercial farm, three similar incidents take place amongst emerging farmers. What makes it worse is that many emerging farmers suffer a total loss of stock - kraals are literally emptied." The NSTF went on to say that 62358 cattle, worth R467.6 million, were stolen between April 2006 and March 2007. Of these, only 27172 animals were recovered, resulting in a loss of R263.9 million. There were also 60967 sheep lost, at a cost of R45, 7 million, and 24075 goats, at a cost of R18 million. "Stock theft has become a business, and there are clear indications of syndicate involvement.

In the period from April 2010 to 31 March 2011, the NSTF - which consists, among others, of representatives from the SAPS, the Red Meat Producers' Association (RMPOs), and the DAFF, reported that 186612 cattle, sheep, and 
goats, with a combined value of approximately R613 million,were reported stolen (Geldenhuys, 2012: 40). In addition, Kempen (2011: 20) reports that, although there has been an 8.2\% decrease in stock theft cases, Minister Mthethwa said that police management was deeply concerned about the number of reported cases. For the 2010/2011 financial year, 30 144 cases were reported, compared to 32 380, the previous report year (2009/2010). The Red Meat Industry Forum (RMIF) urges all industry role-players to co-operate to help prevent stock theft, as this crime stripped the economy of R430 million during the 2011/2012 period, with goats, to the value of R42 million, and, sheep, to the value of million, were stolen. On the negative side, it was further reported that R92 million, and cattle, to the value of R295 million, threatened both the commercial farming sector, as well as the emergent farming sector, in most parts of the country.

According to Brig. Singh (Stock Theft Unit [STU], Head Office, 2011), "Many stock theft court cases are lost because of disputes regarding the positive identification of stolen livestock and the ability to prove ownership. If an animal is marked with a registered brand or tattoo, disputes will be avoided." However, the remarks by the Minister of Police, E.N. Mthethwa, MP, on the occasion of the release of the 2011/2012 SAPS National Crime Statistics, Parliament, Cape Town - 20 September 2012, were highlighted as follows:"During the reporting period last year (2011/2012), we reported to the nation a decline of $8.2 \%$ in the number of reported cases of stock theft but admittedly expressed our dissatisfaction. For the 2011/12 financial year, the decline has been reversed and we experienced a 1.5\% increase. The increase means we need to review our approach because we cannot allow this slight increase to be a trend-setting ratio. If we look at an 8-year period from 2004/05 to date, we see that we had reduced stock theft by $31.2 \%$. Dedicated focus is now being given to the practical implementation of the rural safety strategy. In this regard, particular focus is being given to crossborder crimes, and stock theft, in particular. The Ministry of Police, community organisations, agricultural organisations, and trade unions continue to work together in addressing rural safety. The days of a sizeable portion of stock theft being ascribed to pot slaughtering are long gone. Criminal syndicates are involved (on) a large scale.

According to Maré \& Schutte (2012: 60), "In KZN, 7500 cases of stock theft were reported, 850 of which went to court, and 326 of which were successfully prosecuted. This indicates a success figure of 38.4 percent and 61.6 percent of unsuccessful, untried cases. This is probably an indication of the situation in other provinces as well." The low success rate meant producers no longer report stock theft: "Farmers have lost their trust in the (SAPS) and the Criminal Justice System (CJS)."

Stock theft was not only destroying high potential, genetic material, but threatening the country's food security, making its red meat industry internationally uncompetitive, and negatively impacting the wool industry. It surmised that solving the problem would make "a huge contribution" to the country's self-sufficiency. Furthermore, the stock theft statistics (Table 2, Table 3) for the period 1 April 2010 to 31 March 2011 shows that theft of cattle stabilized during the period 1 April 2010 to 31 March, while the figures for recovered cattle increased by 6\%. Theft of sheep also remained stable, compared to the previous year, while 4\% less sheep were recovered, expressed Maré and Schutte (2012: 60) see the presented tables of statistics overleaf:

Prevalence of livestock theft in selected provinces

Table 2: Livestock stolen and recovered (1 April 2010 to 31 March 2011)

\begin{tabular}{|l|c|c|c|c|}
\hline & $07 / 08$ & $08 / 09$ & $09 / 10$ & $10 / 11$ \\
\hline Cattle stolen & 60163 & 59432 & 61222 & 60600 \\
\hline Cattle recovered & 24663 & 25461 & 24966 & 26458 \\
\hline Sheep stolen & 78332 & 77472 & 90540 & 90017 \\
\hline Sheep recovered & 20209 & 17973 & 19355 & 18541 \\
\hline Goats stolen & 35059 & 38927 & 36927 & 35995 \\
\hline Goats recovered & 11021 & 10576 & 10317 & 10078 \\
\hline
\end{tabular}


Table 3: Losses due to stock theft: National (1 April 2010 to 31 March 2011)

\begin{tabular}{|c|c|c|c|}
\hline Livestock & Action & Number & Rand value \\
\hline Cattle & Stolen & 60600 & R454 500 000 \\
\hline & Recovered & 26458 & R198 435 000 \\
\hline & Loss & 34142 & R256 065 000 \\
\hline Sheep & Stolen & 90017 & R108 020 400 \\
\hline & Recovered & 18541 & R 22 249 200 \\
\hline & Loss & 71476 & R 85 771 200 \\
\hline Goats & Stolen & 35995 & R 50 393 000 \\
\hline & Recovered & 10078 & R 14 109 200 \\
\hline & Loss & 25917 & R 36 283 800 \\
\hline Values: & Cattle R7 500 per unit & Sheep R1 200 per unit & Goats R1 400 per unit \\
\hline
\end{tabular}

With the statistics on the previous section taken into account, the researcher suggests that it is clear to see that South African communities are facing a huge problem of stock theft; thus, measures to curb and manage stock theft within South Africa and across its borders, are a major need, as the data reports reveal.

Geographically, more stock thefts are committed in the provinces indicated in Table 4. With regard to the data, Maré (2012: 3) outlined the areas which had most cattle affected by stock theft between 1 April 2011 to 31 March 2012. Therefore, the ten police stations where most stock theft cases were reported in the period were the following: Qumbu (Eastern Cape); Bityi (Eastern Cape); Utrecht (KwaZulu-Natal); Amersfoort (Mpumalanga); Harrismith (Free State); Bulwer (KwaZulu-Natal); Tsolo (Eastern Cape); Ezakheni (KwaZulu-Natal); Maluti (Eastern Cape); and, Mthatha (Eastern Cape).

Table 4: Police stations with highest incidence of stock theft cases in South Africa

\begin{tabular}{|c|l|l|c|l|l|}
\hline No. & Station & Province & No. & Station & Province \\
\hline 1 & Tsolo & Eastern Cape & 10 & Nqamakwe & Eastern Cape \\
\hline 2 & Maluti & Eastern Cape & 11 & Sulenkama & Eastern Cape \\
\hline 3 & Amersfoort & Mpumalanga & 12 & Bulwer & KwaZulu-Natal \\
\hline 4 & Mthatha & Eastern Cape & 13 & Bergville & KwaZulu-Natal \\
\hline 5 & Bityi & Eastern Cape & 14 & Ermelo & Mpumalanga \\
\hline 6 & Harrismith & Free State & 15 & Nqgeleni & Eastern Cape \\
\hline 7 & Qumbu & Eastern Cape & 16 & Ezakheni & KwaZulu-Natal \\
\hline 8 & Ladysmith & KwaZulu-Natal & 17 & Dannhauser & KwaZulu-Natal \\
\hline 9 & Utrecht & KwaZulu-Natal & & & \\
\hline
\end{tabular}

Geldenhuys (2012: 40) confirmed that the hotspot areas for stock theft are: Qumbu, in the Eastern Cape; followed by Bityi, also in the Eastern Cape; Utrecht, in KZN; Amersfoort, in Mpumalanga; and, Harrismith, in the Free State (Table 5).

Table 5: Stock theft per category: Reported cases and number of units distributed in South Africa (SAPS, 2012)

\begin{tabular}{|l|c|c|c|c|c|c|c|c|c|}
\hline Province & $2004 /$ & $2005 /$ & $2006 /$ & $2007 /$ & $2008 /$ & $2009 /$ & $2010 /$ & $2011 /$ & $\begin{array}{c}\text { No. of Units distributed } \\
\text { in South Africa }\end{array}$ \\
\hline Eastern Cape & 2005 & 2006 & 2007 & 2008 & 2009 & 2010 & 2011 & 2012 & 18 \\
\hline Free State & 9038 & 7537 & 6886 & 7050 & 6808 & 7586 & 7498 & 7554 & 4 \\
\hline Gauteng & 4729 & 4435 & 4700 & 4430 & 5005 & 5033 & 4651 & 4941 & 11 \\
\hline KZN & 682 & 630 & 610 & 655 & 798 & 886 & 711 & 633 & 7 \\
\hline Limpopo & 7816 & 7479 & 7469 & 7600 & 7541 & 7967 & 7402 & 7743 & 8 \\
\hline Mpumalanga & 1642 & 1338 & 1734 & 1341 & 1453 & 1552 & 1663 & 1897 & 7 \\
\hline North West & 2796 & 2362 & 2539 & 2950 & 3155 & 3330 & 2907 & 2912 & 2 \\
\hline Northern Cape & 2765 & 2441 & 2599 & 2488 & 2776 & 3148 & 2728 & 3002 & 8 \\
\hline Western Cape & 2087 & 1686 & 1511 & 1472 & 1600 & 1769 & 1589 & 1485 & 16 \\
\hline RSA & 1120 & 834 & 780 & 792 & 907 & 1109 & 995 & 952 & Total: 81 \\
\hline
\end{tabular}


Through the years (2010-2012), the distribution of stock theft has remained relatively inconsistent per province, as reflected above, to understand stock theft ratio per 100000 of the population; as presented in Table 6:

Table 6: Stock Theft Ratio per 100000 of the population (SAPS, 2012)

\begin{tabular}{|l|c|c|c|c|c|c|c|c|}
\hline Province & $\mathbf{2 0 0 4}$ & $\mathbf{2 0 0 5 /}$ & $\mathbf{2 0 0 6 /}$ & $\mathbf{2 0 0 7 /}$ & $\mathbf{2 0 0 8 /}$ & $\mathbf{2 0 0 9 /}$ & $\mathbf{2 0 1 0 /}$ & $\mathbf{2 0 1 1 /}$ \\
& $\mathbf{2 0 0 5}$ & $\mathbf{2 0 0 6}$ & $\mathbf{2 0 0 7}$ & $\mathbf{2 0 0 8}$ & $\mathbf{2 0 0 9}$ & $\mathbf{2 0 1 0}$ & $\mathbf{2 0 1 1}$ & $\mathbf{2 0 1 2}$ \\
\hline Eastern Cape & 131.1 & 109.3 & 99.9 & 102.1 & 103.5 & 114.1 & 111.2 & 107.7 \\
\hline Free State & 161.1 & 150.1 & 158.8 & 149.7 & 173.9 & 173.4 & 164.7 & 179.0 \\
\hline Gauteng & 7.4 & 6.8 & 6.4 & 6.8 & 7.6 & 8.4 & 6.4 & 5.9 \\
\hline KZN & 79.9 & 76.0 & 75.3 & 75.9 & 74.6 & 76.2 & 69.5 & 71.6 \\
\hline Limpopo & 30.9 & 25.0 & 32.3 & 24.8 & 27.5 & 29.7 & 30.6 & 34.2 \\
\hline Mpumalanga & 81.1 & 68.1 & 72.4 & 83.4 & 87.9 & 92.3 & 80.4 & 79.6 \\
\hline North West & 82.4 & 73.3 & 77.0 & 73.3 & 81.1 & 91.2 & 85.2 & 92.3 \\
\hline Northern Cape & 194.8 & 156.3 & 138.1 & 133.6 & 142.1 & 154.1 & 143.9 & 135.4 \\
\hline Western Cape & 24.5 & 18.0 & 16.4 & 16.4 & 17.2 & 20.7 & 19.0 & 18.0 \\
\hline RSA & 70.1 & $\mathbf{6 1 . 3}$ & $\mathbf{6 0 . 8}$ & $\mathbf{6 0 . 1}$ & 61.7 & 65.7 & 60.3 & $\mathbf{6 1 . 2}$ \\
\hline
\end{tabular}

\section{Structures of Livestock Theft Prevention in South Africa}

There are many structures of livestock theft prevention in across South Africa, however, for the purpose of this study, the italicised 10 structures will be considered by the researcher in an attempt to prevent stock theft. According to Maré (2012, p. 1), stock theft remains one of the most severe problems, with which the South African producer has to contend, but the authorities are serious about combating it. The (Structure 1: National Stock Theft Forum [NSTF]), on which all the stakeholders in the red meat industry, as well as State Departments, are represented, plays an important role in combating stock theft, and have expressed their satisfaction with the strategies of the (Structure 2: Provincial Stock Theft Forum [PSTF]). That said, there are currently eighty-one (81) STUs (Structure/s 3: SAPS members at police station level and SAPS STUs members) in South Africa. Budgets were approved, with a view to expanding STUs in 2012. The Forum welcomed the fact that STUs have now received forensic equipment, and would, in future, only investigate stock theft cases. All stock theft cases will, in future, be investigated, regardless of how many stock were stolen.

During the Operation Duty Calls National Festive Season campaign in 2013 at the SAPS Tshwane Training Academy, Pretoria, Police Minister, N.E. Mthethwa, declared: "for this festive season, our policing approach was not only focused on cities and urban areas, but also rural areas, as part of our rural safety plan. We are pleased to report that we confiscated three-hundred-and-seventy-five (375) stolen cattle, six-hundred-and-twenty-four (624) stolen sheep, and other livestock. As part of sustaining these operations, we are looking into strengthening co-operation with some of our neighbouring countries." In his public lecture in 2012, Mthethwa had stated: "we now have in place a rural safety strategic plan, which gives impetus to our commitment to maintaining rural safety. Over the last year (2011), we have been engaging different rural communities, regarding safety issues. Another aspect of service delivery is improving how our local police stations operate, as well as ensuring that sector policing - which has been on our agenda for some time, is effectively implemented." Now, the (Structure 4: Livestock farmers) wait in anticipation, to see evidence of the Minister's current promise to them in the rural communities.

"Partnership policing has been, and still remains, a priority for visible policing. This does not refer only to communities, but also to a variety of role-players within government, business, municipalities, and interests groups. The creation of partnerships has to occur at all levels, from the national level, right down to the local level. Improving police response is an objective that remains a priority for the Department. The equitable distribution of police stations is essential in ensuring that the services provided by the SAPS, in support of safe and secured communities, is realised by all our people. The mobilisation of (Structure 5: Communities) to participate in combating crime through establishing street committees and community courts, amongst others, remains cardinal in our efforts to eliminate crime. The national, democratic society we are constructing should be founded on a thriving economy, the structure of which should reflect the natural endowments of the country, and the creativity that South African population can offer. Today's event also signifies the important partnership that exists between (Structure 6: Academics in partnerships with relevant stakeholders), (Structure 7: Government in association with local Municipalities); and the role that business is playing in the economic development of our country. Our actions as this collective should communicate a message that encourages a value- 
system that is based on human solidarity that include pride in social activism and respect for an honest day's work. They should include social dissuasion against conspicuous consumption, brazen display of wealth and corruption."

According to the (Structure 8: Portfolio Committee - [PC] on Department of Agriculture, Forestry, and Fisheries (DAFF) (2012), a strategy to fight stock theft in South Africa should include special stock theft courts; members of the PC on DAFF told the Department's acting Director-General, Mr. Peter Thabethe, in Parliament. The Committee Chairperson, Mr. Lulu Johnson, says the DAFF should also collaborate more effectively with other role-players to eliminate stock theft: "Ensure that the (Structure 9: Department of Home Affairs [DHA]) participates in your STUs, to strengthen border controls by SAPS members in conjunction with (Structure 10: South African National Defence Force [SANDF])." SAPS (2012).

\section{Strategies of Combating Livestock Theft in South Africa}

\subsection{National livestock theft prevention initiatives}

At the first Southern African Regional Conference on Stock Theft held in Pretoria from 7 - 10 May 2002, the six Secretariat of the Southern African Regional Police Chiefs Co-operation Organisations (SARPCCO) countries represented mutually agreed on the necessity to draw up guidelines to control the movement of stock. The conference discussed the use of Deoxyribose Nucleic Acid (DNA) technology to aid in the identification of individual animals for the benefit of the livestock industry.

The-said conference resolved to prioritise the following initiatives:

- A training curriculum for member-countries that would focus on prevention, investigation, detection, and joint operations;

- The uniformity of legislation, relating to control, movement, and identification of stock, with a view to harmonizing these laws;

- The enhancement of bilateral operations; and,

- A more efficient exchange of information, including the installation of radio and/or telephone hotlines at identified points along the borders.

At the National Rural Safety Conference (NRSC) hosted by the SAPS National Crime Prevention Division (NCPD) from 23 - 25 October 2001 in Midrand, the observation was made that improved socio-economic development would help to combat stock theft, and that building the prevention of stock theft into plans for developing rural areas is important, since stock theft committed against subsistence farmers dramatically increased their poverty and vulnerability (Department of Community Safety and Liaison, 2008, p. 20). In this regard, other actions undertaken by the NSTF include the following:

- The NSTF is in the process of requesting the National and Provincial Public Prosecuting (NPPP) Authority to appoint experienced prosecutors to handle stock theft cases.

- The National Pound Act is currently with the Department's legal advisers. As soon as it is finalised, it will be forwarded for comment. Meanwhile, it was reported that several provinces had made good progress in the process of finalising the Provincial Pound Acts.

- The Forum requested the Registrar of Animal Identification to declare donkeys as animals, in order to accommodate the compulsory marking of donkeys.

- South African Federation of Livestock Auctioneers (SAFLA) agents, as well as the Red Meat Abattoir Association, were, once again, requested to refuse animals which had not been thoroughly marked.

- Serious cases of animal abuse, during stock theft, are on the increase. Instances where sheep's legs were broken have been reported. (The Society for the Prevention of Cruelty to Animals [SPCA] can be contacted for more information on relevant acts that have been contravened, in this regard, at farm@nspca.co.za.)

- The NSTF, in co-operation with Agriculture South Africa (Agri SA), is in the process of finalising advice on what is acceptable, when dogs are used for hunting, etc. (Maré \& Schutte, 2012, p. 60).

According to the SAPS Manual (2002), in accordance with Section 14 of the Promotion of Access to Information Act (Act No. 2 of 2000) as issued by the information officer of the SAPS in the year 2002, operational response services are regarded as a line function division of the Service, specifically responsible for the maintenance of public order, to conduct high-risk operations through the combating of rural and urban terror, conducting search-and-rescue flights, the stabilisation of volatile situations, and the prevention of cross-border crimes. The division is responsible for national standards, and policy, relating to the issues above. Although there are Operational Response components at area and provincial levels, reporting to the area commissioner, and provincial commissioner, respectively, such components 
function in accordance with national policies, and guidelines, issued by this division. The division has a national capacity for dealing with national Operational Response matters. The division is accountable to the Deputy National Commissioner (Operations).

Furthermore, in relation to the plans to combat stock theft in South Africa, Burger (2007), citing SAPS Strategic Plan (South Africa, 2002a), suggests that the police argue that stock theft, among other crimes, such as: robbery with aggravating circumstances, and other types of robbery and burglary (residential and business premises), can be policed. The term "policed", as it is used here, is explained in a note in the Strategic Plan (South Africa, 2002a, quoted by Burger, 2007) (p. 129): "proactive police action" that can "deter the potential perpetrator from committing a particular crime at a specific place and time." In this sense, the police believe that the crimes listed above can be regarded as "directly preventable" by police action. In further, Burger (2007), citing the Annual Report of the SAPS 2001/2002 (South Africa, 2002b), adds that the-said crimes are labeled as more policeable ... because they can, to a certain extent, be deterred, and, thus, prevented by an increase in conventional policing, for example; visible patrols at the right time, and place; the deployment of plain-clothed police officials; roadblocks; police warnings to the public; stop-and-search actions; and, cordon-and-search operations (p. 129).

Oosthuizen (in Geldenhuys, 2010) observes that, in a period of three years (2007-2009), the police had focused on the alignment of the STUs. During this process, they reviewed the units' locations, to determine whether they were easily accessible to the service area. He went on to say that they also looked at areas where there had been a sharp increase in stock theft, and where there were established STUs; for example, Greytown, in KZN; Vereeniging, in Gauteng; Butterworth, Qumbu, and King William's Town, in the Eastern Cape; Kwa-Mahlangu, in Mpumalanga; and, Musina and Giyani, in Limpopo province. Other role-players, such as the DAFF, also have plans in place to combat stock theft. In May 2010, members of the Portfolio Committee on DAFF told the Department's acting Director-General, Mr. Peter Thabethe, in Parliament, that a strategy to fight stock theft in South Africa should include special stock theft courts (p. 38). In essence, they are of the opinion that these special courts, and legislation, would allow stiffer fines/sentences for thieves, and contribute to solving the stock theft problem. Safety in rural areas is high on the agenda, and in September 2010, Mr. Nathi Mthethwa announced that rural safety units would be resurrected.

\section{Challenges towards Effective Stock Theft Prevention}

\subsection{Police institutional Capacity}

And policing stock theft in Giyani communities: the challenges revealed the under mentioned herein. The first question to be addressed is "Do the SAPS have adequate capacity to respond to the challenges implied by stock theft in the Giyani Policing Area? Why do they think so?"

This was one of the questions posed to the participants. One participant had this to say:

"I have 25 years as a police officer and 12 years under Giyani STU as a Warrant Officer, through my years of experience I can tell you that the challenge brought by stock theft is most members of this unit are deployed in rural areas during the day, where stock theft is most problematic, and that is when the stock thieves are not operating. Climate change, such as drought which cause a lack of food and laziness to our rural people also pose a serious challenge, as during this time majority of us do not know the best way to make a living, poverty and hunger as poor people provide a market for cheap stolen stock even when they are not directly involved in theft can be cited as another challenge to this crime." KII (Giyani SAPS STU Commander).

Staffing remains the major problem at the Giyani police station. The one main police station in Giyani is staffed by463 police officers, who have been assigned to all the units, with few active police reservists. (Researcher's note: that is a police-population ratio of 1:463, i.e. 1 police officer to every 463 citizens.) The Stock Theft Unit is only staffed by seven (7) personnel; and, again, Giyani boasts 04 satellite police stations: Dzumeri; Makhuva; Bendstore; and, Muyexe, consisting of less than 15 officers per satellite.

The station is faced with serious challenges, such as (in order of importance):

- Lack of resources.

- Lack of manpower.

- Resistance to learning new approaches to policing. Most of the officers are Black African individuals, who have been working at the station for more than 10 years, and are not well-disposed to learning new practices to policing. 
- Giyani still has to be resourced for the four satellite stations, which fall under its jurisdiction, so as to have officials that directly deal with stock theft cases.

\subsection{Police Corruption}

Police corruption was also cited as one of the challenges thereof, it was suggested that high number of SAPS officers and employees still involved in corrupt, and fraudulent, incidents of crime, as well as the seriousness, thereof, is alarming, and unacceptable to the management of the SAPS. Not a day goes by without the media reporting on an incident, or incidents, of SAPS officers, reservists, or employees being arrested for involvement in criminal activities.

"... When we call them (the SAPS) they do not respond immediately, if they come, they can only do so after 4 hours. In some instances we go to the police station only to be told they are no vehicles to attend to us. However, the close villages to the inner city are the most problematic, villages such as Makosha (ward 14), Mavalani (ward 20) and Siyandhani". FGD No. 2 (Makosha village community leader).

\subsection{Allegations of SAPS and Department of Justice officials' involvement in stock theft}

During the focus group discussions, it emerged that the police are alleged to be involved in stock theft in Giyani. As incidents of theft increase, some livestock farmers, officials at the DAFF in Giyani, as well as members of the public, said they knew those who are involved, but were afraid of victimisation. Some threatened to take the law into their own hands to protect their animals, as they did not know who to turn to, citing police involvement as very disturbing. The livestock farmers said they were under siege, and alleged that the police collude with criminals. One emerging farmer said he had lost all his cattle, saying nine (9) of his cows were stolen in January 1996, and no-one had been arrested. The majority of Giyani residents cite vigilantism as a solution to problems caused by stock theft.

\subsection{Increased case workload, and the performance of the Giyani SAPS STU}

During the FGDs, it emerged that the increased workload, due to a diversity of challenges, such as: staff shortages; a lack of skills; low morale; and, inadequate training, hamper the performance of the STU in adequately responding to incidents of stock theft within the Giyani Policing Area.

Participants were of the view that a variety of capacity challenges hampered the performance of the Giyani SAPS STU, and the coding of their responses showed that the following were being experienced as challenges in this unit:

- Huge workload;

- Poor investigation of stock theft cases;

- Recruitment, skills development, and advanced training;

- Lack of resources;

- Giyani STU members are not professionally trained and dedicated; and,

- The Giyani STU act in isolation (i.e., without other stakeholders) in approaching stock theft:

This views of participants revealed that there was a serious skills-and-experience deficit within the STU to enable it to adequately respond to fraud syndicates. From these views, it seems as if some of the detectives are simply not adequately-trained to perform certain functions, such as profiling of modus operandi. The implications for the SAPS are that it is vital for the management to facilitate, and support, continuous in-service training, so as to alleviate the skills shortage. The results of the study agree with the findings of Mofokeng (2010, p. 15, citing Van Vuuren, 1997; Schnonteich, 2001; 2002; \&, Minnaar, 2008), the huge workload carried by detectives make any proper and thorough investigation impossible.

In support of this view, Minnaar (2008, in Mofokeng, 2010, p. 115) explains that a "heavy caseload tends to mean that detectives take shortcuts or simply mark dockets as 'undetected', or 'witness/es cannot be traced / found', or 'insufficient evidence available' - all in an effort to reduce their caseloads." It was quite revealing to note that the current strategies of the Giyani SAPS STU, with regard to stock theft, are ineffective. The study revealed that the Giyani SAPS STU do not have the necessary capacity to respond to stock theft crime. The participants shared the same belief that they (the Giyani SAPS STU) do not have the ability to identify the challenges related to stock theft. It was found that they do not have creative policies and plans to co-ordinate the prevention of stock theft in Giyani.

The participants stated that the Giyani SAPS STU have various challenges, which disrupt their police work. There is a shortage of personnel in the Giyani STU; thus, there is a need for more personnel to be assigned to the satellite units 
in Giyani, as well as to the main Giyani STU. The officers attached to the local police station, and additional officers, should be recruited, or retained at the service centre. However, they should, first, undergo training in stock theft investigation. This arrangement will afford investigators at the local police station level the opportunity to become familiar with all aspects, relating to the investigation of stock theft. Giyani STU officers should assist the latter, where necessary. This would also ensure that the principle of an integrated approach is maintained. Distances, and the availability of informers, were also considered important. It was said that this should be discussed regularly between the local police station Commander, and the Giyani STU commander. It was further revealed that there is a need to work out how limited resources could efficiently be managed by the Giyani STU. It seems there is a lack of proper management of those scarce resources, and the police cannot account for how their vehicles are not in good condition for operations on stock theft. Given that rural people use alternative structures, such as community policing, and the livestock forum, there is a need to capacitate, monitor, and evaluate those systems, to see whether they have an impact on, and adhere to, the measures aimed at the prevention of stock theft.

\subsection{Long and inconclusive Court Procedures}

The finding further illustrates that the performance of the Department of Justice: Giyani Magistrate Courts in the GPA is known, in terms of disposal of stock theft cases. The efficiency of the Magistrates' courts of law in handling stock theft cases is questionable, owing to their inadequate understanding of traditional markings, and colours, that local people are accustomed to using in livestock. Thus, the majority of rural residents argued that customary courts would be best-suited to handle stock theft cases, because the Tihosi (kings), who preside over such cases in these courts, understand, and have profound knowledge of, livestock and stock theft cases. They further argued that some leeway should be given to stock owners to choose between whether they wanted their cases tried by the customary courts, or Magistrates' courts, to avoid the loophole of manipulating the whole system, since the Magistrates' courts are not well-versed in matters of stock theft, and are corrupt. In most cases, perpetrators of stock theft engage government in lengthy and expensive cases that waste the tax payers' money, employing sophisticated lawyers who, more often than not, end up winning the cases on technicality grounds. These defence lawyers deploy sophisticated legal jargon that witnesses in stock theft cases - who, in most cases, are uneducated rural dwellers - fail to comprehend. We must not forget that the perpetrators, in most of these cases, are wealthy; so, they can afford to hire shrewd lawyers and advocates, who end up letting them off their crimes. The complexity of the Magistrates' Court procedures, and the involvement of defence lawyers, prevents justice from prevailing in stock theft cases. Livestock farmers in Giyani acknowledged the inadequacies that the courts are faced with in dealing with stock theft cases. Therefore, in stock theft cases, courts should be provided with assessors who have vast knowledge of such issues. The victims of this crime should, also, know the procedures to follow, if they decided to follow an appeals route.

\section{Conclusions and Recommended Good Practices}

From the data analysed, it became clear that stock theft is high in the GPA, and the current preventative measures against stock theft in the area under study, and elsewhere, are slow to give dividends; thus, there is a long way to go to eradicate it completely. This suggests that the strategies implemented so far have not been successful. These inefficiencies should be corrected, and some other strategies that could be employed include: Intelligence-led operations - based on the FGDs, KIls, and stock theft courtroom observations, one area that still needs improving by the SAPS is the use of information gathered through intelligence, and enforcement, to provide a better understanding of the causes, and consequences, of stock theft syndicates in the GPA. The implications, for the Giyani SAPS STU, are that it would be very useful for the Unit Commander at the Giyani SAPS STU, as well as the PSTU within Limpopo Province, to use, amongst others, information gathered through intelligence, and investigations from scholarly research, geared towards a theoretical and empirical understanding of the causes of stock theft, including an understanding of one-time, or chronic, offenders, and the risk factors that fostered their criminality, as well as the risk factors that created the opportunities for stock theft crime. The introduction of intelligence-led raids, and drives, should be of importance, to monitor well-known syndicates across the policing areas.

Importantly, in aligning with technological advances and improvements the Giyani SAPS STU should introduce the use of technological advances made, as an essential means to detect stock theft, i.e., the usage of computers; staging of database system; proper facilitation of crime trends; and, surveillance, to eradicate increasing stock theft crimes in the GPA. It is advisable to have access to, and share, information, irrespective of physical locations. Policing stock theft in Giyani should be modernised in our post-modern society, to keep up with current trends; this will enhance the daily 
operations of the Giyani SAPS STU. This would contribute to addressing the stock theft problem successfully in the GPA.

\section{References}

Burger, F.J. 2007. Strategic perspectives on crime and policing in South Africa. Van Schaik Publishers: Hatfield, Pretoria.

Butler, L.E. 2012.Stock theft is 'crippling SA'. The Herald (Online). Available from: http://www.peherald.com/news/article/3662. [Accessed: 03/12/2012].

Collins, T. 2011. Stock theft losses. The Witness, June, 10:11.

Crime Stats South Africa [ONLINE]. 2012. Available from: crimestatssa.com/toptnbyprovince.p... [Accessed: 25/02/2012]..

Geldenhuys, K. 2009.Forensics - physical matching \& brand-mark examination on livestock. Servamus - Community-Based Safety \& Security Magazine, October: 48-49.

Geldenhuys, K. 2010.Stock Theft - and what owners can do to protect their stock. Servamus - Community-Based Safety \& Security Magazine, November: 38-41.

Geldenhuys, K.2012.Stock theft workshop in Pretoria.Servamus - Community-Based Safety \& Security Magazine, June: 40.

Independent Online [ONLINE]. 2007. Stock theft hits emerging farmers hard. Oct 22. Available from: http://www.iol.co.za/news/ southafrica/stock-theft-hits-emerging-farmers-hard-1.375891?ot=inmsa.ArticlePrintPageLayout.ot [Accessed: 01/02/2012].

Marè, J. 2012. National Stock Theft Forum - report - RPO congress. 2012. Available from: http://www.rpo.co.za/rpo/StockTheft ReportSeptember2012.pdf. [Accessed: 04/12/2012].

Maré, J \& Schutte, G. February 2012. Livestock theft figures.Stock farm: Pretoria.

Mofokeng, J.T. 2006. Perceptions on corruption in the Crime Prevention Units of the saps in Pretoria area. Mini-dissertation submitted in partial fulfilment of the requirements for thedegree Magister Technologiae: Policing. Department of Safety and Security Management, Faculty of Humanities: Tshwane University of Technology: Pretoria.

Mofokeng, J. T. 2010. Anti-fraud training in the South African Police Service (SAPS): A strategic perspective. Unpublished Doctor Technologiae: Policing Thesis. Pretoria: Tshwane University of Technology.

Mthethwa, E.N. 2010. A focus on the future plans of the South African Police Service, in the short term and medium term, remarks by the Minister of Police, E.N. Mthethwa, MP at the American Chamber of Commerce in SA dinner .The Castle Kyalami, Gauteng, 24 November 2010. Available from: http://www.saps.gov.za/_dynamicModules/internetSite/newsBuild.asp?myURL=1068 [Accessed: 05/12/2012].

Mthethwa, N. 2011. Public Lecture by the Minister of Police, Nathi Mthethwa, MP titled: "The Big Debate - Crime and its impact on Business" Graduate Business School, Westville Campus University of KwaZulu-Natal, Durban, 17 November 2011. Available from: http://www.saps.gov.za/_dynamicModules/internetSite/newsBuild.asp?myURL=1357 [Accessed: 23/11/2012].

Mthethwa, E.N. 2011. SAPS Remarks by the Minister of Police, EN Mthethwa, MP on the occasion of the release of the National Crime Statistics, Sheraton Hotel, Pretoria, Gauteng Sep 8, 2011. Available from: http://www.info.gov.za/speech/DynamicAction? pageid=461\&sid=21437\&tid=42271. [Accessed: $21 / 11 / 2012$ ].

South Africa. 1996. The Constitution of the Republic of South Africa as adopted by the Constitutional Assembly on 8 May 1996 and as amended on 11 October 1996. Pretoria: Government Printer. (B34B-96).

South Africa (SA). Department of Police. 2012. South African Police Service Strategic Plan 2010-2014 [Online]. Available from: http://www.saps.gov.za/saps_profile/strategic_framework/strategic_plan/2010_2014/strategic_plan_2010_2014.pdf [Accessed: 10/01/2012].

South Africa. 2002. Manual of the South African Police Service in accordance with section 14 of the promotion of access to information Act, 2000 (Act no. 2 of 2000). Issued by the information officer of the South African Police Service 2002. Available from: http://www.saps.gov.za/docs_publs/legislation/paia/english/part1.pdf. [Accessed: 10 /06/2012].

South Africa. 2011. Stock Theft Act, No. 57 of 1957. Juta Law, 46 (34535), Sep 30:1-2.

South African Police Service Pilot's Cabin. 2006. Volume 5, issue 2. Stock theft, Sep 2006, Vol 5. Available from: http://www.rpol.co.za/files/stock_theft.pdf [Accessed: 10/06/2012].

South African Police Service. 2012. Crime research and statistics - SAPS - per category: Stock theft: Stock theft in RSA Available from: http://www.saps.gov.za/statistics/reports/crimestats/2012/categories/stock_theft.pdf. [Accessed: 28/09/2012].

South African Police Service. 2012(a). Police Population Rations. Department of police [Online]. Available from: http://www.saps.gov. zal_dynamicModules/internetsite/buildingBlocks/basePage4/BP444.asp [Accessed: 21/09/2012].

South African Police Service New Bill. 2012. Bill to curb stock theft for public comments. Available from: http://www.saps.gov.za/ docs_publs/legislation/new/1-35269_19-4_police.pdf [Accessed: 21/09/2012].

South African Police Service - Research Unit. 2010. An overview of stock theft in South Africa, May 20. Available from: http://www.pmg.org.za/report/20100526-overview-stock-theft-south-africa [Accessed: 21/09/2012].

South African Police Service. 2002. Stock Theft Unit Investigator's Course - Manual A, 22 January. G.P.-S. 002-9178. 